\title{
Identification of gene products expressed in the developing chick visual system: characterization of a middle-molecular- weight neurofilament cDNA
}

\author{
Dieter Zopf, Irm Hermans-Borgmeyer, Eckart D. Gundelfinger, and Heinrich Betz \\ Zentrum für Molekulare Biologie, Universität Heidelberg, Im Neuenheimer Feld 282, D-6900 Heidelberg, Federal Republic of \\ Germany
}

\begin{abstract}
A cDNA library enriched for transcripts that accumulate from embryonic day 7 until day 1 posthatching was constructed from poly $(\mathbf{A})^{+}$RNA of chick optic lobe tissue. From this library, three recombinants were isolated that correspond to neural mRNAs appearing during the major period of synaptogenesis in the retinotectal system. One of these recombinants (OZ 11) was identified as a middle-molecular weight neurofilament (NF-M) cDNA which, together with two overlapping clones, encodes part of the rod and the entire tail region of NF-M. In situ hybridization revealed NF-M mRNA to be highly expressed in regions of the chick central nervous system, which contain multipolar and/or long-projection neurons.
\end{abstract}

[Key Words: Selective cloning; neurofilament; in situ hybridization; central nervous system; synaptogenesis]

Received April 3, 1987; revised version accepted June 29, 1987

A major problem in neurobiology concerns the formation of specific synaptic connections during development of the nervous system (Jacobson 1978; Purves and Lichtman 1985). So far, only a few of the gene products expressed during synaptogenesis have been identified at the molecular level [see Kandel (1983) and references therein]. Others involved in directional axonal growth, process branching, growth cone recognition, target cell positioning, and so forth, are still unknown. Here, we describe an attempt to isolate mRNAs accumulating during the major period of synapse formation.

We have chosen the developing chick visual system as a suitable model system for a molecular cloning approach for several reasons. (1) Synaptogenesis in the vertebrate retinotectal system has been investigated particularly well by morphological and electrophysiological techniques. Both a high specificity and considerable plasticity of the projections established by the optic nerve from the retina to its target neurons in the optic tectum have been documented in detail (reviewed in Sperry 1963; Jacobson 1978; Purves and Lichtman 1985). (2) Retinal ganglion cells develop independently of the rest of the central nervous system (CNS) and project in a single tract to the brain. This not only allows separate analysis of gene expression in both the projecting neurons and their target area but also facilitates experimental manipulations of synaptic development in lower vertebrates (Freeman 1977; Fujisawa et al. 1984; Thanos et al. 1984). (3) The time course of formation of retinotectal projections is described precisely for the chick. Here, retinal ganglion cells stop proliferating between embryonic days 3 and $8(E 3-8)$ and start axon formation between days 5 and 7 (E5-7) (Goldberg and Coulombre 1972; Kahn 1974). At days E7-8, the first contacts between retinal growth cones and tectal cells are established. Retinotectal synaptogenesis reaches a maximum between days E10 and E14 and then declines (Crossland et al. 1975). At hatching, the chick visual system is functionally mature. (4) The avian retina and optic tectum are large neuronal structures, thus providing enough tissue for isolating mRNA even at early stages of embryonic development.

To provide a first basis for the identification of "differentiation-specific" mRNAs, we have prepared an optic lobe cDNA library enriched in gene transcripts which accumulate during the major period of retinotectal synapse formation. Three recombinants corresponding to mRNAs appearing between day E7 and day 1 posthatching (P1) were studied. One of these cDNAs is shown to encode part of the chick middle-molecularweight neurofilament (NF-M) protein. In situ hybridization experiments show that NF-M mRNA is highly expressed in multipolar and long-projection neurons in the postnatal chick CNS.

Results

Isolation of differentiation-specific cDNA clones

A variety of strategies has been developed to select for tissue- or differentiation-specific cDNAs (Milner and Sutcliffe 1983; Sargent and Dawid 1983; Anderson and 
Axel 1986). Using an approach similar to that of Davis et al. (1984), we prepared a cDNA library enriched for transcripts that accumulate in the chick optic lobe during formation of the retinotectal projection (see Fig. 1).

In a first analysis, the enriched cDNA library was screened with radiolabeled cDNA probes prepared from poly $(\mathrm{A})^{+}$RNA of day-P1 chicken liver and optic lobe, respectively. About $40 \%$ of the phage plaques did not hybridize, and from the remaining $60 \%$, about twothirds were positive with both probes. Of the clones that only hybridized to the optic lobe probe, 50 were isolated. Three of these (clones OZ 8, OZ 11, and OZ 19) were chosen randomly for further analysis, and their specificity confirmed on Northern blots (Fig. 2A). The mRNAs corresponding to these clones are highly expressed in optic lobe at day P1 but are neither detectable in optic lobe at day E7 nor in liver at day P1.

Clones OZ 8 and OZ 19 contained small inserts of 280 bp and $380 \mathrm{bp}$, repectively. Both hybridized in Northern blots to mRNAs of about $2.7 \mathrm{~kb}$ (Fig. 2A). Their nucleotide sequences, however, were unrelated, and their hybridization patterns in genomic Southern blots were different (to be published elsewhere).

OZ 11 represents a neuronal and differentiationspecific $m R N A$

The tissue- and stage-specific expression of clone OZ 11 was studied in more detail by Northern blot analysis.

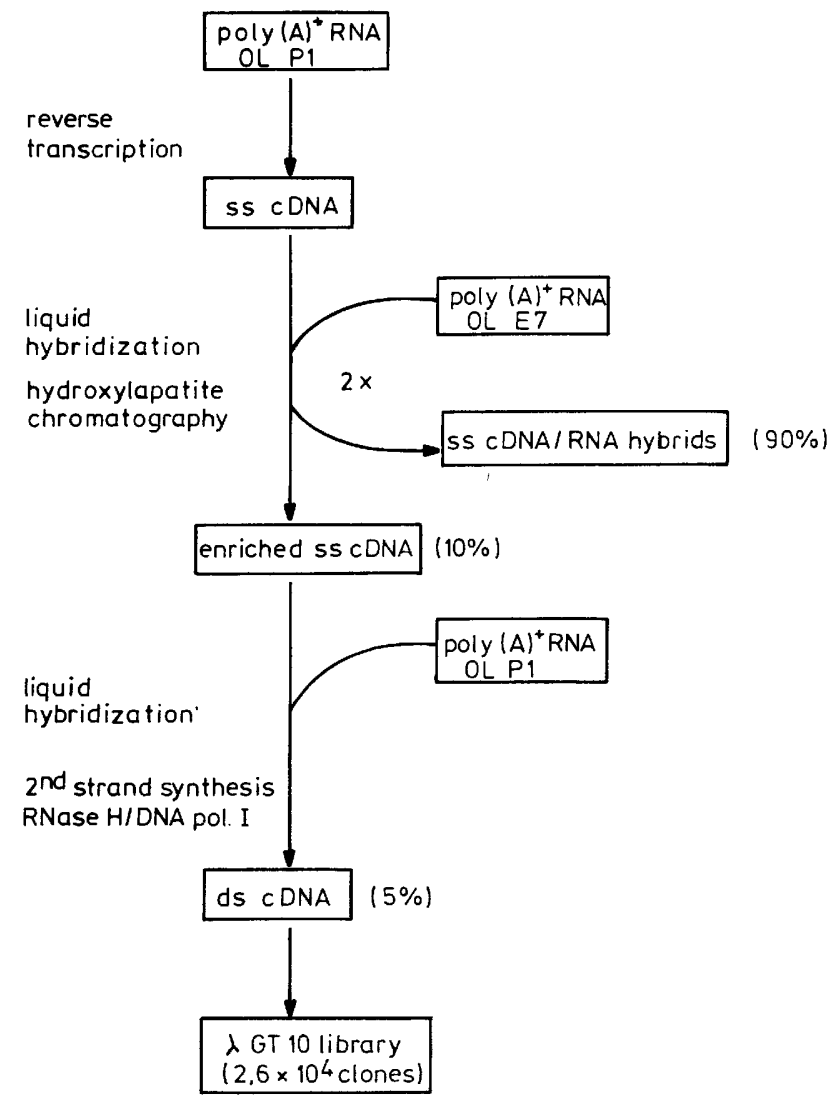

Figure 1. Strategy for construction of the enriched cDNA library (for details, see Materials and methods).

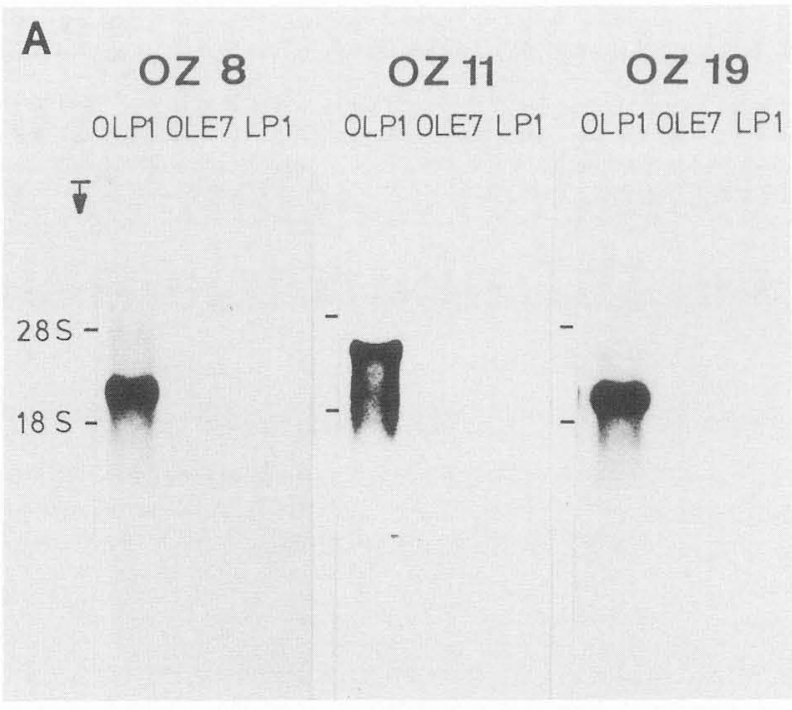

B

\section{1}
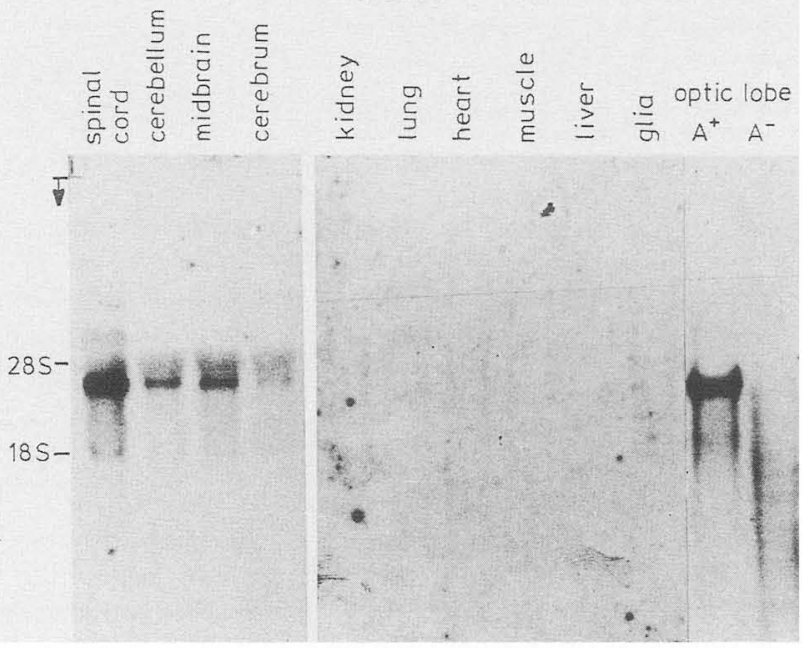

C

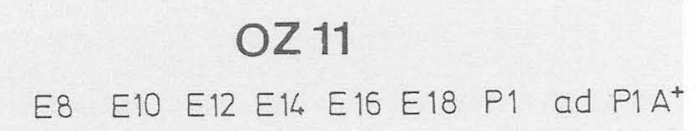

$\bar{\nabla}$

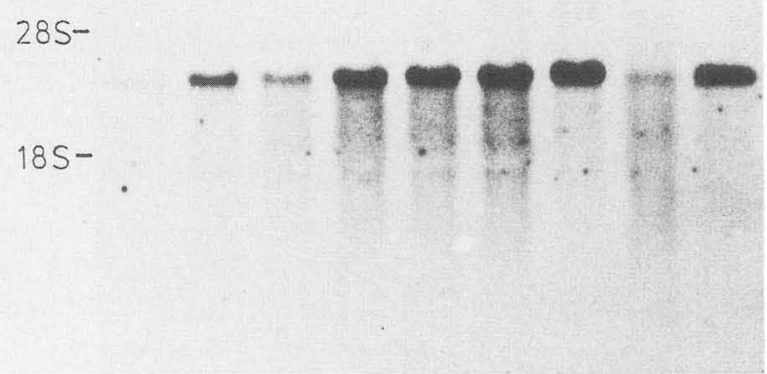

Figure 2. (See facing page for legend.) 
This clone contained an insert of $1.25 \mathrm{~kb}$, which hybridized to an mRNA of about $3.6 \mathrm{~kb}$ of day-P1 optic lobe poly(A)+ RNA (Fig. 2A). At this stage of development, the same mRNA is also expressed in other parts of the nervous system (Fig. 2B). Its level of expression was highest in spinal cord, intermediate in midbrain and cerebellum, and low in cerebrum. No hybridization signals were detected with poly $(\mathrm{A})^{+}$RNA from kidney, lung, heart, muscle, liver, and primary glial cell cultures of optic lobe tissue (Fig. 2B).

During the development of the chick optic lobe, $\mathrm{OZ}$ 11 mRNA was found first at day E8, increased until day $\mathrm{P} 1$, and thereafter dropped to a lower adult level (Fig. 2C).

On a genomic Southern blot, the OZ 11 insert hybridized to a single 7.4-kb fragment of HindIII-digested DNA (Fig. 3). EcoRI and PstI produced two and three hybridizing fragments, respectively. These results suggest that the OZ 11 gene is represented only once in the haploid genome (cf. restriction map in Fig. 4A).

To isolate longer cDNA clones, $7 \times 10^{5}$ recombinants of a second cDNA library, prepared from total optic lobe poly(A) ${ }^{+}$RNA (day P1), were screened with the OZ 11 insert. From 60 hybridization-positive plaques, two overlapping clones, $\mathrm{OZ} 11 / 2$ and $\mathrm{OZ} 11 / 18$, were isolated, which extended the sequence of OZ 11 at the $5^{\prime}$ and $3^{\prime}$ ends, respectively. Figure $4 \mathrm{~A}$ shows the restriction map and the alignment of the OZ 11 cDNA clones. Their combined nucleotide sequence of 2148 bases is presented in Figure 4B. Starting from the first nucleotide, there is one long open reading frame encoding a polypeptide sequence of 509 amino acids (calculated molecular weight, $56 \mathrm{kD}$ ). The $3^{\prime}$-untranslated region of 621 nucleotides contains five potential polyadenylation sites, AATAAA, one of which starts 26 bp upstream of the 3 ' end of the OZ 11/18 cDNA. Because the length of the corresponding mRNA is $\sim 3.6 \mathrm{~kb}, \sim 1.4 \mathrm{~kb}$ of the mRNA sequence is still lacking.

\section{OZ 11 encodes the NF-M protein}

A computer-assisted search in sequence data banks revealed a striking homology between the amino-terminal region of the protein sequence encoded by the OZ 11 cDNAs and the carboxy-terminal region of the central

Figure 2. Expression of $\mathrm{OZ} 8, \mathrm{OZ} 11$, and $\mathrm{OZ} 19$ transcripts. Northern blot analysis was performed as described in Materials and methods. Origin (arrow) and positions of $28 \mathrm{~S}$ and $18 \mathrm{~S}$ rRNAs are indicated. $(A)$ Poly $(\mathrm{A})^{+}$RNA $(1 \mu \mathrm{g} /$ lane $)$ isolated from optic lobe at days P1 (OLP1) and E7 (OLE7), and from liver at day $\mathrm{P} 1$ (LP1), was probed with radiolabeled OZ 8, OZ 11, and OZ 19 DNAs. Exposure times were $1.5 \mathrm{hr}$ for OZ 8, OZ 19 and $7.5 \mathrm{hr}$ for OZ 11 . One-week exposures revealed no additional bands. $(B)$ RNAs extracted from various tissues of day-P1 chicken were hybridized with the OZ 11 probe. (Left panel) 10 $\mu \mathrm{g} /$ lane of total RNA. (Right panel) $1 \mu /$ lane of poly|A)+ RNA; as control, $10 \mu \mathrm{g}$ of optic lobe poly(A)- RNA was included. Exposure times were $15 \mathrm{hr}$ (left panel) and 5 days (right panel). (C) Total RNA of chick optic lobe $(10 \mu \mathrm{g} / \mathrm{lane})$, isolated at various developmental stages (ad, adult), was hybridized with the $\mathrm{OZ}$ 11 probe. Day-P1 poly $(\mathrm{A})^{+} \mathrm{RNA}\left(\mathrm{P}^{+} \mathrm{A}^{+}\right)(1 \mu \mathrm{g})$ served as control. Exposure time was $8 \mathrm{hr}$.

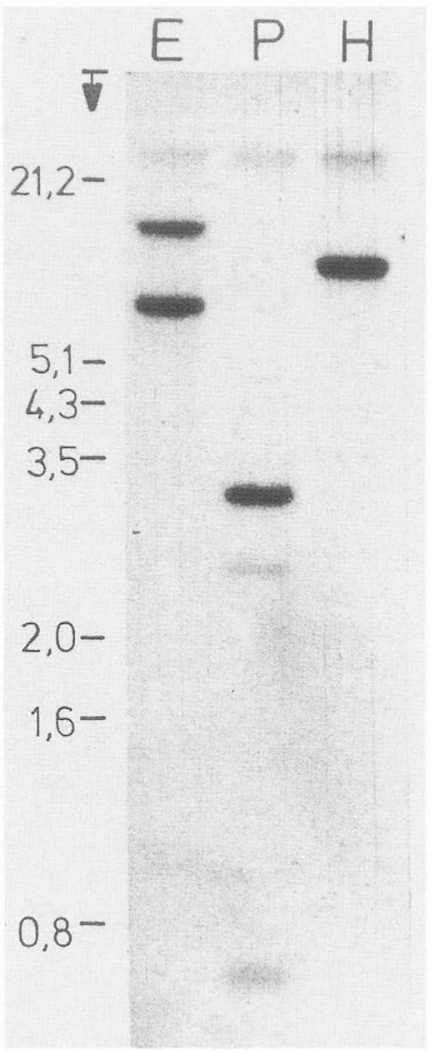

Figure 3. Southern blot analysis of chicken genomic DNA with the $\mathrm{OZ} 11$ probe. Each lane contained $10 \mu \mathrm{g}$ of genomic DNA digested with restriction endonucleases EcoRI (E), PstI $(\mathrm{P})$, and HindIII $(\mathrm{H})$, respectively. The origin is marked by an arrow. DNA markers are given on the left in kilobases.

$a$-helical rod domain of intermediate filament (IF) proteins. This rod region is highly conserved in all known IF proteins (Weber and Geisler 1984). The common structural model for these proteins contains additional hypervariable amino-terminal (head) and carboxy-terminal (tail) domains. The exclusive neuronal expression of the OZ 11 mRNA and the length of the tailpiece of the predicted protein prompted us to compare it with the published partial protein sequences of the porcine NF-M protein (Geisler et al. 1984). Our sequence extends 58 amino acids into the conserved rod domain; 55 residues thereof are conserved between chicken and pig (Fig. 4B). Of the three exchanges, two are isofunctional, whereas the third one is a Gln-His substitution. The subsequent 23 amino acids of the porcine NF-M protein have also been determined by Geisler et al. (1984); 16 are identical in the chick protein. An additional peptide sequence of 18 residues within the tail region of the porcine NF-M protein (Geisler et al. 1984) is completely conserved in the chick polypeptide (amino acid positions 100-117 in Fig. 4B). We therefore conclude that we have cloned a major part of the NF-M protein from chicken. The three NF proteins are mainly characterized by the different lengths of their unique tails (Geisler et al. 1984, 1985a, b). The OZ 11 clones code for the complete tail regions 
Zopf et al.

A
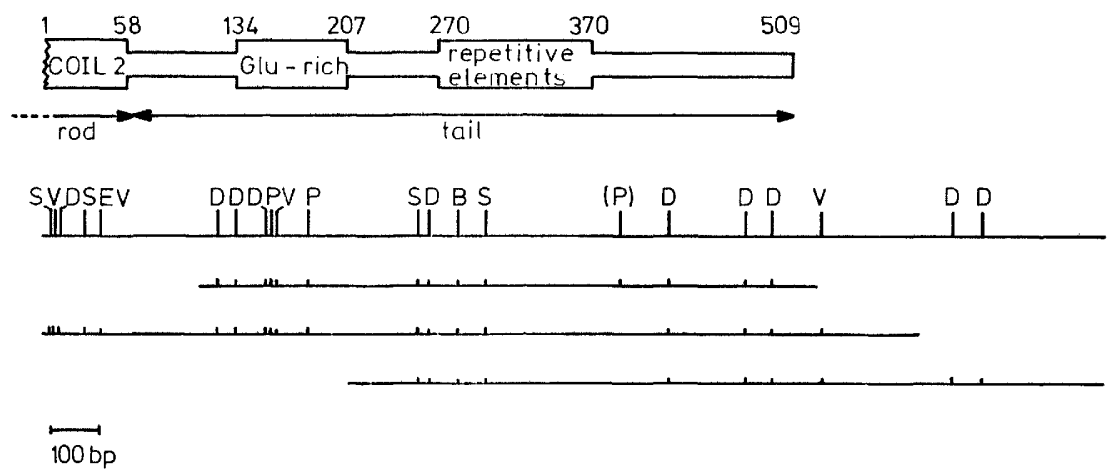

OZ 11

OZ 11/2

OZ 11/18

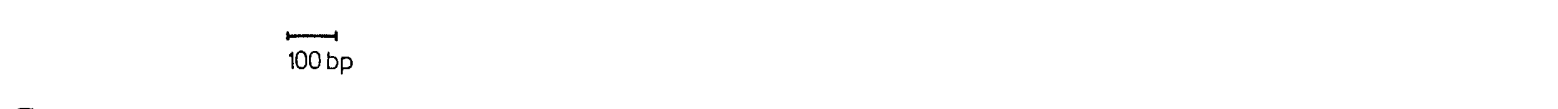

B

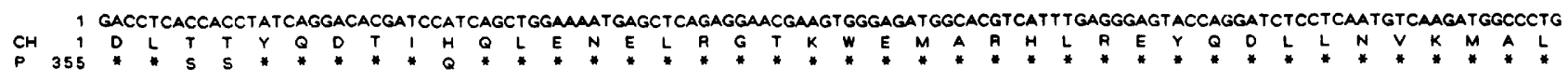
-

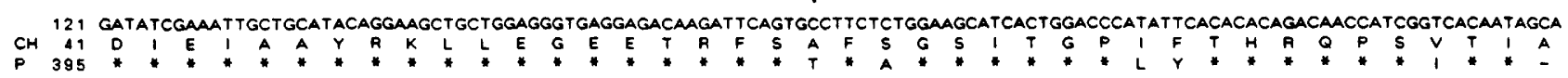

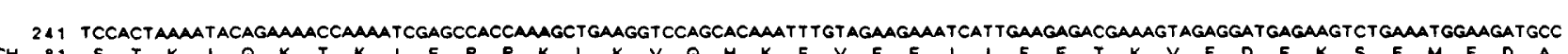

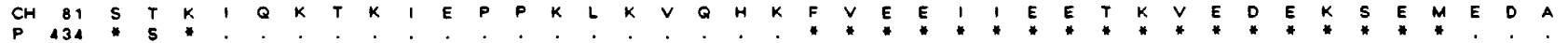

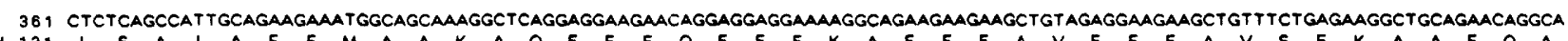
CH 121 L S A I A E E M A A K A Q E E E Q E E E K A E E E A V E E E A $V$ S

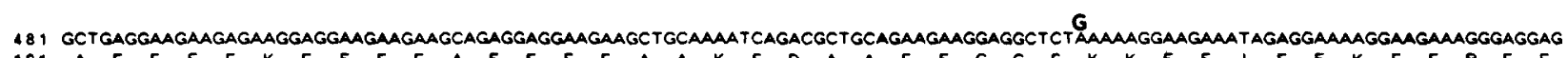
CH 161 A E E E E K E E E E A E E E E A A K S D A A E E G G S K K E E I E E K E E R E E

601 GCTGAAGAAGAAGAAGCTGAAGCCAAGgGCAAAGCTGAAGAGGCAGgTGCAAAGgTAGAMANAGTGAAATCACCTCCTGCAAAGTCACCCCCTAAATCCCCCCCTAAATCCCCTGTAACA CH 201 A E E E E A E A K G K A E E A G A K V E K V K S P P A K S P P K S P P K S P V T

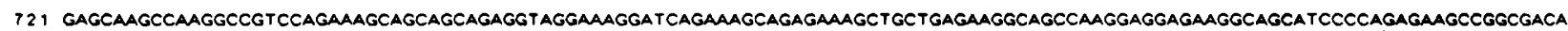

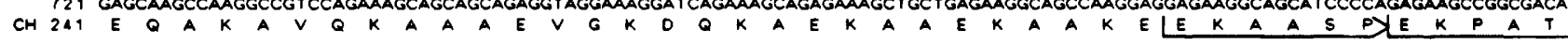

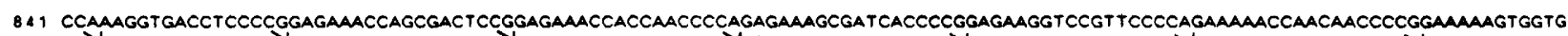

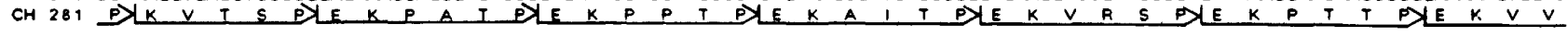

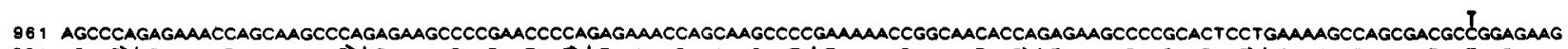

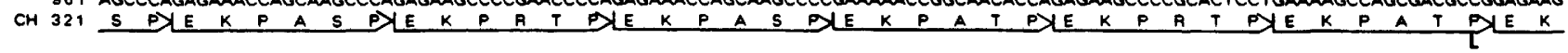

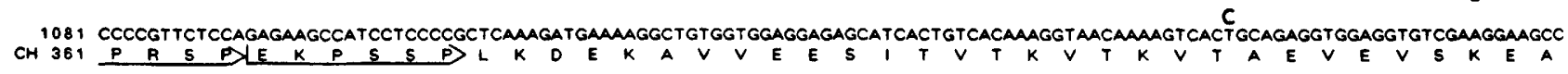

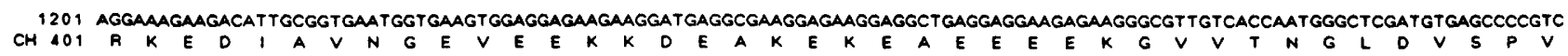

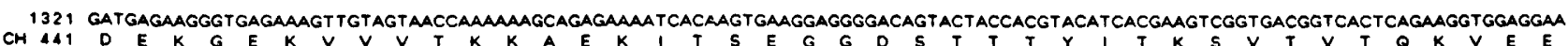

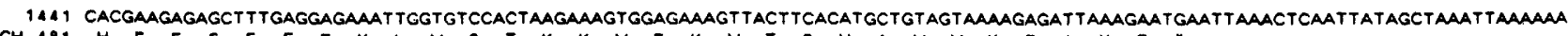
CH 181 H E E S F E E K L V S T K K V E K V T S H A V V K E I K E

1561 AAATTAAAGAGCTTGgGTCGgTGCAAAAGGTTAAGCCATATGACAGCT GCAAAATGCATGTGAGTGACGgCTTTAAAGCAGAACGGGTTCTCTCATGGAGGCTCCAGACACACAGTATTT 1681 TAC TCTTTTGTGCAATATAGGGGAGGGGGGGGGAATGCATGCAGGCTCAAGATGTGCTCCCTCCACAGAGCT TGGGGAACTAAATAAANAATAATAAAAANAAATAATAAAAATACTAAT 1801 AATAGTGCATGAGT TGAAATGTGCAAAGGAACCTTTTGAATTTCCTGAGCTGTTGGAGGGACGTATCTGAGGAACGACTTAAGATGTATTATGCAAAGAACCAACTGAGCCAAAACCAAA

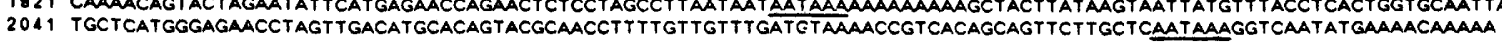

Figure 4. Physical map and sequence of chicken NF-M cDNA clones. $(A)$ Partial restriction endonuclease map and alignment of three overlapping cDNA clones. Only relevant cleavage sites are indicated. (B) BstEII; (D) DdeI; (EV) EcoRV; (P) PstI (S) Sau3A; (V) PvuII. The PstI site in parentheses was found only in OZ 11. A schematic diagram of the deduced NF protein structure is presented. Characteristic regions referred to in the text are emphasized, and amino acid positions defining their borders (as numbered in $B$ ) are given. $(B)$ Sequence of NF-M cDNA and protein. Nucleotide numbers are to the left of the sequence. The five potential polyadenylation signals are underlined. The deduced amino acid sequence $(\mathrm{CH})$ is aligned with the first homologous amino acid residue (position $355)$ of the published partial polypeptide sequence of porcine NF-M $(P)\left(\right.$ Geisler et al. 1984) $\left({ }^{*}\right)$ Identical; $(\cdot)$ not determined; $(-)$ deleted amino acid residues. Hexapeptide repeats are enclosed in open arrows. Microheterogeneities are indicated above and below the respective sequence. 
of NF-M, hence, unequivocally specifying this protein and distinguishing it from the low-and high-molecularweight NF proteins NF-L and NF-H, respectively.

Recently, Julien et al. (1986) published a partial murine NF-M cDNA sequence that encodes parts of the $\alpha$ helical rod and the carboxy-terminal tail regions. An overlap of 134 amino acids between the chick (residues 1-135) and the murine (residues 32-165) sequences exhibits high homology $(90 \%)$. Although the following 54 amino acids of the carboxy-terminal extension of the predicted murine NF-M protein include many glutamic acid residues, no alignment with the chicken protein could be obtained.

Analysis of the protein sequence revealed two characteristic domains within the tail region of the NF-M protein. Fifty-five percent of the amino acids between positions 134 and 207 are glutamic acid residues. A comparable region is found in the murine and porcine NF-L proteins, where $54 \%$ and $51 \%$, respectively, are glutamic acids (Geisler et al. 1985a; Lewis and Cowan 1985, 1986; Julien et al. 1986). Another unusual region follows between positions 270 and 370 . It consists of a hexapeptide that is repeated 17 times and has a consensus sequence of Glu-Lys-Pro/Val/Ala-X-Ser/Thr-Pro. There are two interruptions of this motif. A glutamic acid residue is deleted in repeat 3 , and a nucleotide microheterogeneity ( $\mathrm{T}$ or $\mathrm{C}$ at position 1073) between the different $\mathrm{OZ}$ 11 clones contributes to either proline or leucine at the last position of repeat 15 . Other nucleotide heterogeneities were found among the three cDNA clones (Fig. 4B). One allows either lysine or glutamic acid at amino acid position 188, whereas the others do not affect the polypeptide sequence.

\section{NF-M mRNA: a marker for multipolar and long- projection neurons in the chick CNS}

The localization of NF-M mRNA in the chick CNS was analyzed by in situ hybridization experiments. Because $\mathrm{OZ} 11$ was originally derived from poly(A) ${ }^{+}$RNA of the optic lobe and was found there at high levels at day P1 (Fig. 2A, C), transversal sections of the chick brain presenting the midbrain with the optic lobes were hybridized with a radiolabeled $\mathrm{OZ} 11$ probe. The sections used (Fig. 5A) contain both central pathways as well as motor neurons and primary sensory cells. Table 1 summarizes the results obtained.

Figure 5 shows some examples of positive hybridization. Within the midbrain, the most intense labeling seen in our experiments occurred in the motor neurons of the nucleus trochlearis (NT) (Fig. 5C, D) and the nucleus oculomotorius (Fig. 6A). Their axons combine to the nervus trochlearis and nervus oculomotorius, which innervate various muscles of the eye. The axons of the fasciculus longitudinalis medialis (FLM), which is located below the NT and was cross-sectioned here (Fig. $5 \mathrm{C}, \mathrm{D}$, exhibited only background labeling, comparable to that seen upon hybridization with radio-labeled vector DNA (Fig. 5B). This confirms NF-M mRNA to be located in perikarya, as was also shown for mouse NF-L mRNA (Liesi et al. 1986).
Table 1. CNS regions exhibiting positive hybridization with the $O Z 11 \mathrm{cDNA}$ probe

\begin{tabular}{l}
\hline Cerebellum \\
Nucleus cerebellaris \\
Purkinje cells \\
Midbrain \\
Nucleus trochlearis (NT) \\
Nucleus isthmoopticus (ION) \\
Nucleus trigeminus radicis mesencephali \\
Nucleus linearis caudalis \\
Nucleus mesencephalicus profundus \\
Nucleus oculomotorius \\
Optic lobe \\
Nucleus isthmi pars principalis parvocellularis (IPC) \\
Nucleus isthmi pars principalis magnocellularis (IMC) \\
Stratum griseum centrale (SGC) \\
Lamina i of stratum griseum et fibrosum superficiale (SGFS)
\end{tabular}

Data are taken from sections hybridized as described in the legends to Figs. 5 and 6. For anatomical details, see Jungherr (1969).

In the optic lobe, the most prominent labeling was exhibited by the two isthmic nuclei, nucleus isthmi pars parvocellularis (IPC) and nucleus isthmi pars magnocellularis (IMC) (Fig. 5E,F). These nuclei receive afferents from and project back to selected layers of the ipsilateral optic tectum (Hunt and Brecha 1984). Furthermore, two layers of the laminated optic tectum showed significant hybridization. The inner layer was identified as stratum griseum centrale (SGC). This stratum contains a fairly homogeneous population of large multipolar neurons that provide the major efferent pathway of the optic tectum. It projects to the reticular formation and to the nucleus rotundus (Hunt and Brecha 1984). The second smaller and more superficial layer, labeled by silver grains, was assigned to lamina i of the stratum griseum et fibrosum superficiale (SGFS). This stratum is subdivided into 10 laminae, designated $a-j$ according to Cowan et al. (1961). Predominantly radial neurons are located within lamina $i$. They give rise to the topographically organized efferent projections of the optic tectum to various nuclei in the CNS [IPC, IMC, nucleus isthmoopticus (ION), etc.].

In the cerebellar folds, strong hybridization was found along the demarcation line between the molecular and the granular cell layer (Fig. 5G,H). Its scattered appearance and location indicate that these signals originated from the large Purkinje cell bodies. In situ hybridization confirms this interpretation at the level of individual cells (Fig. 6B). Purkinje cells possess the most elaborate dendritic arborization found in the brain and provide the major output of the cerebellar cortex.

\section{Discussion}

The data presented in this paper demonstrate that the construction of enriched cDNA libraries, using prehybridization with poly $(\mathrm{A})^{+}$RNA from undifferentiated tissue, facilitates the identification of neural mRNAs that appear during defined stages of embryonic development. A major advantage of using an enriched cDNA li- 

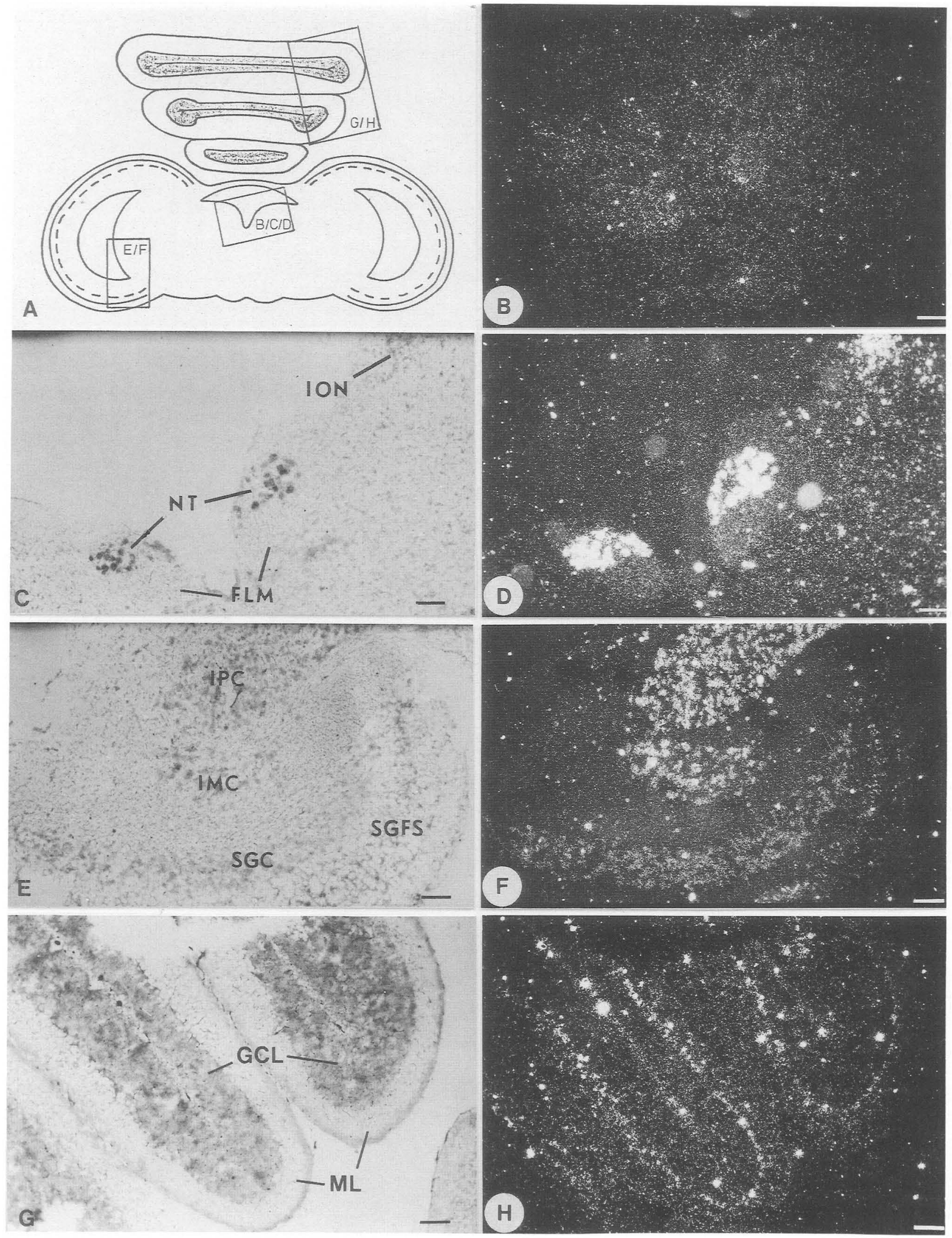

Figure 5. (See facing page for legend.) 
brary is not only preselection of clones of interest but also the ease with which the comparatively small number of resulting recombinants can be handled for screening. The selectivity of the cloning procedure may be increased by choosing a more narrow window of development. Furthermore, its sensitivity may be improved by subjecting the cDNA probe used for screening to a subtraction protocol analogous to that followed for library construction (Scott et al. 1983).

Of several putative neural recombinants isolated in our library, three that were characterized further represented gene products regulated during optic lobe development. One, OZ 11, was identified as a cDNA of the NF-M subunit of the chick NF triplet (Shaw et al. 1984). NFs are thought to be important determinants of neuronal geometry and axonal diameter (Hoffmann et al. 1984; Lasek et al. 1985). The precise role of the NF-M subunit within the filaments is, however, not known.

Assuming that the highly conserved amino-terminal portion of chick NF-M has a size similar to that of the corresponding regions of porcine NF-M /Geisler et al. 1984), its total molecular weight is estimated to be about $95 \mathrm{kD}$. The discrepancy between this calculated weight and the apparent molecular weight of $160 \mathrm{kD}$ seen upon SDS-polyacrylamide gel electrophoresis (Weber et al. 1983; Lee et al. 1986a) is probably due to the highly charged tail region of this group of IF proteins (Kaufmann et al. 1984). The complete sequence of the NF-M tail defines two structural domains potentially involved in filament-protein interactions and functional regulation. A glutamate-rich region of about 70 amino acids has been found in all NF proteins analyzed so far (Geisler et al. 1985a; Lewis and Cowan 1985, 1986; Julien et al. 1986). Comparison of chicken and available mammalian NF-M sequences indicates that only the acidic character, and not the primary structure of this domain, is conserved between vertebrates. It may be crucial for the visualization of neuronal processes by the Bodian silver stain (Gambetti et al. 1981). The hexapeptide repeat Glu-Lys-Pro/Val/Ala-X-Ser/Thr-Pro defines a presumably highly structured domain of NF-M; its hydroxylated amino acid residues may represent the major sites of phosphorylation of this IF protein. Previous work has shown that the tail regions of the two larger NF polypeptides are phosphorylated extensively in vivo by a special NF kinase (Jones and Williams 1982; Julien and Mushynski 1982; Carden et al. 1985; Geisler et al. 1985b; Wible et al. 1986). The phosphorylated sites define highly immunogenic epitopes that can occur in repetitive sequences along individual subunits (HogueAngeletti et al. 1985; Liem et al. 1985). Their tentative

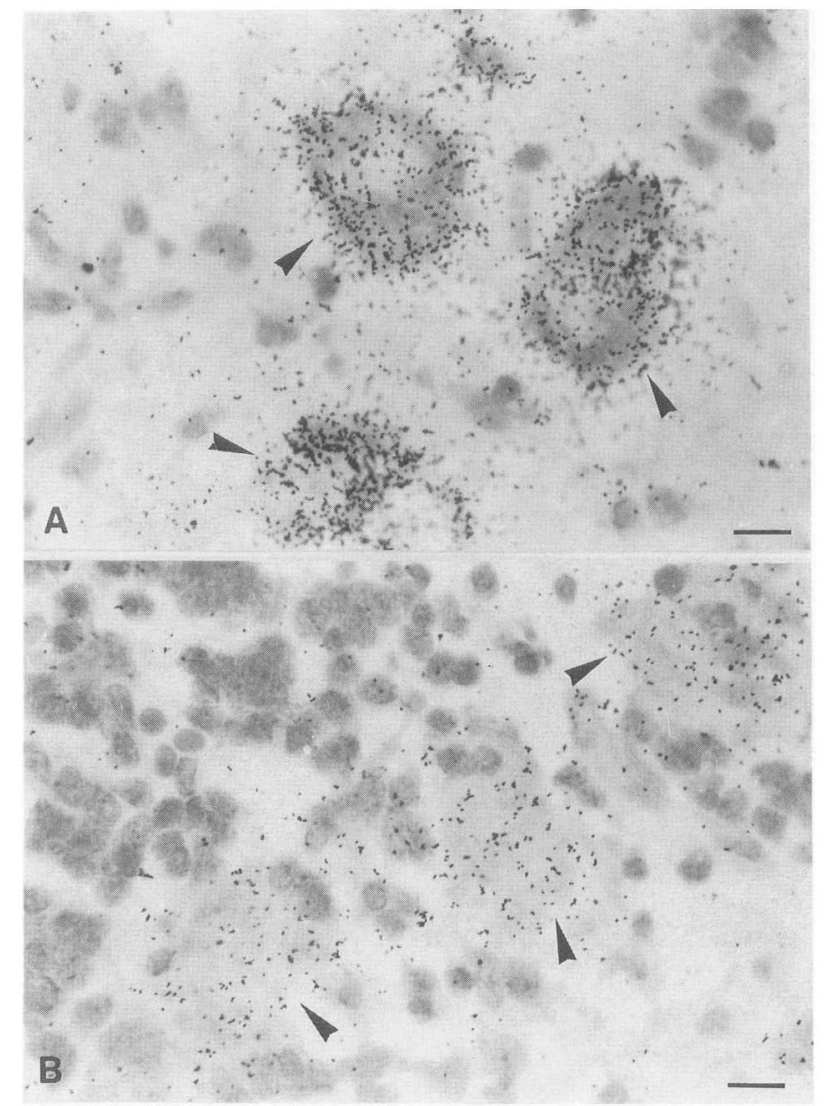

Figure 6. Localization of NF-M mRNA in motor neurons (arrowheads) of the nucleus oculomotorius ventromedialis $(A)$ and Purkinje cells (B) at day P1 by in situ hybridization with OZ 11. Omitting deproteination steps, tissue sections were hybridized and washed as described (Shivers et al. 1986). Bar, 10 $\mu \mathrm{m}$.

location coincides with the position of the repeat structure identified here (Julien and Mushynski 1983; Lee et al. 1986a). Also, the number of 17 repeats predicted from the chicken cDNA sequence fits with the stoichiometry of phosphate incorporation reported for different mammalian NF-M preparations $(9-26$ moles phosphate per mole protein; see Jones and Williams 1982; Julien and Mushynski 1982; Ksiezak-Reding and Yen 1986). The function of the phosphorylated domains is unknown, but they may be important for the interaction with other axonal proteins, as they are located peripherally to the 10-nm backbone of the filament (Julien and Mushynski 1983; Weber et al. 1983; Hirokawa et al. 1984). Monoclonal antibodies specific for phosphorylated and non-

Figure 5. In situ localization of NF-M mRNA in the day-P1 chick CNS. (A) Schematic drawing of the examined transversal sections of the chick brain, showing the midbrain region, the optic lobes, and the cerebellar folds (above). Boxes indicate areas from which the photographs in $B-H$ have been taken. $(B)$ Dark-field photomicrograph of control experiments in which consecutive sections to $C$ and $D$ were hybridized with ${ }^{35}$ S-labeled pUC18 plasmid DNA. No specific hybridization was detectable. $(C-H)$ In situ hybridization signals obtained with ${ }^{35}$ S-labeled $\mathrm{OZ} 11$ probe in the midbrain region $(C, D)$, the basolateral optic lobe $(E, F)$, and in the cerebellum $(G$, $H$ ) are displayed in dark-field (right) and bright-field (left) photomicrographs. Note that the dark labeling of the NT in $C$ does not derive from Giemsa histological staining but from silver grains. Bar, $200 \mu \mathrm{m}$. (FLM) Fasciculus longitudinalis medialis; (GCL) granular cell layer; (ML) molecular layer. (For other abbreviations, see Table 1 and text.) 
phosphorylated neurofilament polypeptides, respectively, can bind differentially to axonal and perikaryal NF proteins (Bennet and DiLullo 1985; Peng et al. 1986; Lee et al. 1986b). Phosphorylation of NF proteins thus might occur after transport to neuronal processes.

The in situ hybridization data obtained here show that NF-M mRNA is expressed preferentially in brain regions containing neurons that have either long axons and/or highly ramified dendritic arborizations. For example, the cell layers of the optic tectum providing its major efferent pathways, the isthmic nuclei projecting to the ipsilateral tectal halves, the sensory nucleus trigeminus radicis medialis, and the Purkinje cell layer in the cerebellum were found to give strong hybridization signals in the posthatching chick CNS. Particularly impressive was the labeling of the NT and the nucleus oculomotorius, which both contain far-projecting motor neurons of the midbrain. In situ hybridization with the NF-M cDNA probe thus provides a tool to differentiate cell bodies of multipolar and long-projection neurons from those of local circuit cells in the CNS. This technique enlarges the existing repertoire of classical neuroanatomical staining procedures that unselectively visualize either neuronal perikarya (Nissl stain) or their processes (Bodian silver stain). Quantitative approaches to NF-M mRNA expression in the developing brain may provide information about the onset of neuronal differentiation and neurite formation. Also, even subtle developmental changes, like elimination of multiinnervation or programmed cell death (Cowan et al. 1984), may be studied.

\section{Materials and methods}

Fertilized eggs and male chickens of day-P1 white leghorn were obtained from a local hatchery. Eggs were incubated at $38^{\circ} \mathrm{C}$ at $75 \%$ humidity. Tissue pieces were frozen in liquid nitrogen for nucleic acid extraction or used immediately for in situ hybridization.

\section{$D N A$ and RNA isolation and analysis}

High-molecular-weight DNA was isolated from chicken optic lobe (Maniatis et al. 1982). Genomic DNA was digested and electrophoresed in $1 \%$ agarose gels. Southern transfer and hybridization were performed as described by Herrmann et al. (1986), with a final wash at $70^{\circ} \mathrm{C}$. Total cellular RNA was extracted from frozen tissue, either according to Chirgwin et al. (1979) or as described by Cathala et al. (1983). Poly(A)+ RNA was obtained by oligo/dT)-cellulose chromatography (Aviv and Leder 1972). For Northern blot analysis, RNA was separated on $1 \%$ agarose $/ 2.2 \mathrm{M}$ formaldehyde gels (Maniatis et al. 1982) and transferred to Hybond $\mathrm{N}$ membranes (Amersham) in $20 \times$ SSC. RNA was immobilized by UV cross-linking and visualized with Methylene Blue (Maniatis et al. 1982). Prehybridization and hybridization were performed in $50 \%$ formamide, $5 \times$ SET $(1 \times$ SET: $150 \mathrm{~mm} \mathrm{NaCl}, 30 \mathrm{~mm}$ Tris- $\mathrm{HCl}$ at $\mathrm{pH} 8.0$, and $1 \mathrm{~mm}$ EDTA), $10 \times$ Denhardt's solution (Denhardt 1966), 0.1\% (wt/vol) SDS, $0.1 \%(\mathrm{wt} / \mathrm{vol})$ sodium pyrophosphate, $250 \mu \mathrm{g} / \mathrm{ml}$ denatured herring sperm DNA, and $10 \mu \mathrm{g} / \mathrm{ml}$ polyadenylic acid at $42^{\circ} \mathrm{C}$. After prehybridization for at least $5 \mathrm{hr}$, hybridization was carried out overnight with $1 \times 10^{6}$ to $2 \times 10^{6} \mathrm{cpm} / \mathrm{ml}$ of the radiolabeled probe. Isolated cDNA inserts were radiolabeled to specific activities of $5 \times 10^{7}$ to $1 \times 10^{8} \mathrm{cpm} / \mu \mathrm{g}$ by nick-trans- lation in the presence of $\left[\alpha^{-32} \mathrm{P}\right] \mathrm{dCTP}$ (Amersham Buchler) Filters were washed twice for $30 \mathrm{~min}$ in $2 \times \mathrm{SET}, 0.1 \%$ (wt/ vol) SDS, and $0.1 \%(\mathrm{wt} / \mathrm{vol})$ sodium pyrophosphate, two to three times for $30 \mathrm{~min}$ in $0.2 \times \mathrm{SET}, 0.1 \%(\mathrm{wt} / \mathrm{vol}) \mathrm{SDS}$, and $0.1 \%(\mathrm{wt} / \mathrm{vol})$ sodium pyrophosphate at $65^{\circ} \mathrm{C}$, and exposed to Kodak X-ray film.

\section{Construction of cDNA libraries}

cDNA was synthesized from poly(A)+ RNA of day-P1 chick optic lobe using the protocol of Gubler and Hoffmann (1983). Double-stranded cDNA (ds cDNA) was methylated with EcoRI methylase, treated with T4 DNA polymerase to generate blunt ends, and ligated to phosphorylated EcoRI linkers. EcoRI-digested cDNA was size-fractionated on Sepharose-CL-4b. Fragments greater than $600 \mathrm{bp}$ were ligated into the $E c 0 \mathrm{RI}$ site of $\lambda$ gyl0 (Huynh et al. 1985), packaged in vitro, and amplified on Escherichia coli C600 Hfl. A library of $3 \times 10^{6}$ independent clones was established.

For the construction of an enriched cDNA library, singlestranded cDNA (ss cDNA) was reverse-transcribed from poly $(\mathrm{A})^{+}$RNA of day-P1 chick optic lobe primed with oligo$(\mathrm{dT})_{(12-18)}($ Biolabs $)$ in the presence of actinomycin $\mathrm{D}(40 \mu \mathrm{g} / \mathrm{ml})$. $\left[\alpha-{ }^{32} \mathrm{P}\right] \mathrm{dCTP}$ was added to give a specific activity of $1 \times 10^{6}$ $\mathrm{cpm} / \mu \mathrm{g}$ ss cDNA. The RNA was removed by alkaline hydrolysis, and the cDNA excluded from Sephadex G50. The cDNA was hybridized with a 20 -fold excess of poly $(\mathrm{A})+$ RNA of day-E7 chick optic lobe at an RNA concentration of $2 \mathrm{mg} / \mathrm{ml}$ in $0.5 \mathrm{M}$ phosphate buffer (pH 6.8) [passed over Chelex 100 (Biorad) to remove divalent cations], $1 \%$ (wt/vol) SDS in sealed siliconized glass capillaries. After boiling for $60 \mathrm{sec}$, hybridization was performed at $68^{\circ} \mathrm{C}$ for $20 \mathrm{hr}$ (uncorrected $R_{0} \mathrm{t}$ of $\sim 440$ ). Upon hydroxylapatite chromatography in $0.12 \mathrm{M}$ phosphate buffer $\mathrm{pH}$ 6.8 at $60^{\circ} \mathrm{C}$, about $80 \%$ of the cDNA remained bound to the column. The fractions containing the unhybridized cDNA were concentrated with 2-butanol and desalted on Bio-Gel P60, and the cDNA subjected to a second round of hybridization. Here, RNA was in 50-fold excess (final concentration of $1 \mathrm{mg} / \mathrm{ml}$ ), and the hybridization was for $40 \mathrm{hr}$ (uncorrected $R_{0} \mathrm{t}$ as above). Another $50 \%$ of the cDNA fraction was removed after hydroxylapatite chromatography. The remaining cDNA was then hybridized to the homologous poly $(\mathbf{A})^{+} \mathrm{RNA}^{+}$, using conditions specified for the second round of hybridization. The second cDNA strand was synthesized in the presence of trace amounts of $\left[\alpha^{32}\right.$ P]dCTP (Amersham), using RNase H and DNA polymerase I (Gubler and Hoffmann 1983) with an efficiency of $50 \%$. ds cDNA was processed as above and cloned into $\lambda$ gt 10 to give a selected cDNA library of $2.6 \times 10^{4}$ independent recombinants.

Plaque screening of the enriched cDNA library was performed as described (Mason and Williams 1985), using $1 \times 10^{6}$ to $3 \times 10^{6} \mathrm{cpm} / 150-\mathrm{mm}$ filter of cDNA probes (sp. act. $5 \times 10^{7}$ to $1 \times 10^{8} \mathrm{cpm} / \mu \mathrm{g}$ ) reverse-transcribed from oligo/dT)-primed poly $(\mathrm{A})^{+}$RNA in the presence of $\left[\alpha^{32} \mathrm{P}\right] \mathrm{dCTP}$ (Amersham). For the isolation of overlapping cDNA clones, filters were hybridized with $1 \times 10^{5} \mathrm{cpm} /$ filter of nick-translated cDNA insert.

\section{Subcloning and DNA sequencing}

cDNA inserts from hybridization-positive and plaque-purified phages were subcloned into the plasmid vector pUC18 and into M13 phages mpl8 and mpl9 (Norrander et al. 1983). DNA sequences were obtained using the dideoxy chain termination method of Sanger et al. (1977). Computer-assisted sequence analysis was performed using the BSA program library of the DKFZ (Heidelberg). 


\section{Glial primary cell cultures}

Optic lobes from 15-day-old chick embryos were dissociated by trypsinization. After resuspension in Dulbecco's modified Eagle's medium, containing $10 \%$ fetal calf serum and antibiotics, the cells were seeded in uncoated plastic culture flasks (NUNC). The cells were grown at $37^{\circ} \mathrm{C}$ in a humidified atmosphere of $95 \%$ air $/ 5 \% \mathrm{CO}_{2}$ for 7 days (equivalent to day $\mathrm{P} 1$ ). The cells were harvested in phosphate-buffered saline (PBS), containing 2 mM EDTA, and used for RNA preparation. By morphological criteria (Betz and Müller 1982), less than $5 \%$ of the cells were judged to be neurons.

\section{In situ hybridization}

Fresh brain tissue was washed briefly in PBS and fixed in $4 \%$ (wt/vol) paraformaldehyde in PBS overnight at $4^{\circ} \mathrm{C}$. The tissue was washed for $12 \mathrm{hr}$ with three changes of $5 \%$ (wt/vol) sucrose in PBS and embedded in OCT embedding medium (Miles). Frozen tissue sections of $8 \mu \mathrm{m}$ were cut and mounted on gelatinized slides. Further treatment and preparation of sections for hybridization was performed according to Hafen et al. (1983). Plasmid DNA was radiolabeled with $\left[\alpha^{35}\right.$ S]dATP (Amersham Buchler) to specific activities of $1 \times 10^{9}$ to $2 \times 10^{9} \mathrm{cpm} / \mu \mathrm{g}$ DNA, according to Feinberg and Vogelstein (1983), and digested with DdeI (cf. Fig. 4A) to produce small-sized fragments for hybridization. Hybridization conditions were as described (Hafen et al. 1983), using $2 \times 10^{5} \mathrm{cpm} / \mathrm{slide}$. Hybridization and wash solutions contained $10 \mathrm{~mm}$ dithiothreitol (DTT). Slides were exposed to Kodak NTB-2 emulsion for 1 week and stained for 1-2 min with Giemsa (Sigma).

\section{Acknowledgments}

We thank C. Udri, C. Schröder, and H. Krischke for expert technical assistance, Dr. C.-M. Becker for criticism and advice on anatomy, Drs. M. Osborn and K. Weber for fruitful discussion, Drs. G. Bilbe, W. Franke, and H. Rehm for critical reading of the manuscript, and I. Nonnenmacher and J. Rami for help during its preparation. This work was supported by the Bundesministerium für Forschung und Technologie (BCT 381 5) and the Fonds der Chemischen Industrie.

\section{Notes added in proof}

The sequence published in this paper has been submitted to EMBL/GenBank.

After submission of this manuscript, Myers et al. (EMBO /. 6: 1617-1626) published the entire sequence of the human NF-M protein. The latter also contains a repeated amino acid sequence within the tail region, which, however, differs from that of the chick protein.

\section{References}

Anderson, D.J. and R. Axel. 1985. Molecular probes for the development and plasticity of neural crest derivatives. Cell 42: 649-662.

Aviv, H. and P. Leder. 1972. Purification of biologically active globin messenger RNA by chromatography on oligothymidilic acid-cellulose. Proc. Natl. Acad. Sci. 69: 1403-1412.

Bennett, G.S. and C. DiLullo. 1985. Slow posttranslational modification of a neurofilament protein. I. Cell Biol. 100: 1799-1804.

Betz, H. and U. Müller. 1982. Culture of chick embryo neural retina in serum-free medium. Exp. Cell Res. 138: 297-302.

Carden, M.J., W.W. Schlaepfer, and V.M.-Y. Lee. 1985. The structure, biochemical properties, and immunogenicity of neurofilament peripheral regions are determined by phosphorylation. J. Biol. Chem. 260: 9805-9817.

Cathala, G., I.-F. Savouret, B. Mendez, B.L. West, M. Karin, J.A. Martial, and J.D. Baxter. 1983. A method for isolation of intact, translationally active ribonucleic acid. DNA 2: 329335.

Chirgwin, J.M., A.E. Przybyla, R.J. MacDonald, and W.J. Rutter. 1979. Isolation of biologically active ribonucleic acid from sources enriched in ribonuclease. Biochemistry 18: 52945299.

Cowan, M.W., L. Adamson, and T.P.S. Powell. 1961. An experimental study of the avian visual system. J. Anat. 95: 545562.

Cowan, M.W., J.W. Fawcett, D.D.M. O'Leary, and B.B. Stanfield. 1984. Regressive events in neurogenesis. Science 225: 1258-1265.

Crossland, W., M.W. Cowan, and L.A. Rogers. 1975. Studies on the development of the chick optic tectum. IV. An autoradiographic study of the development of retino-tectal connections. Brain Res. 91: 1-23.

Davis, M.M., D.I. Cohen, E.A. Nielsen, M. Steinmetz, W.E. Paul, and L. Hood. 1984. Cell-type specific cDNA probes and the murine I region: The localization and orientation of Ad. Proc. Natl. Acad. Sci. 81: 2194-2198.

Denhardt, D.T. 1966. A membrane-filter technique for the detection of complementary DNA. Biochem. Biophys. Res. Commun. 23: 641-646.

Feinberg, A.P. and B. Vogelstein. 1983. A technique for radiolabeling DNA restriction endonuclease fragments to high specific activity. Anal. Biochem. 132: 6-13.

Freeman, J.A. 1977. Possible regulatory function of acetylcholine receptor in maintenance of retinotectal synapses. $\mathrm{Na}$ ture 269: 218-222.

Fujisawa, H., S. Thanos, and U. Schwarz. 1984. Mechanisms in the development of retinotectal projections in the chick embryo studied by surgical deflection of the retinal pathway. Dev. Biol. 102: 356-367.

Gambetti, P., L. Autilio-Gambetti, and S.C. Papasozomenos. 1981. Bodian's silver method stains neurofilament polypeptides. Science 213: 1521-1522.

Geisler, N., E. Kaufmann, S. Fischer, U. Plessmann, and K. Weber. 1983. Neurofilament architecture combines structural principles of intermediate filaments with carboxy-terminal extensions increasing in size between triplet proteins. EMBO I. 2: 1295-1302.

Geisler, N., S. Fischer, J. Vandekerckhove, U. Plessmann, and K. Weber. 1984. Hybrid character of a large neurofilament protein (NF-M): Intermediate filament type sequence followed by a long and acidic carboxy-terminal extension. EMBO I. 3: 2701-2706.

Geisler, N., U. Plessmann, and K. Weber. 1985a. The complete amino acid sequence of the major mammalian neurofilament protein (NF-L). FEBS Lett. 182: 475-478.

Geisler, N., S. Fischer, J. Vandekerckhove, J. Van Damme, U. Plessmann, and K. Weber. 1985b. Protein-chemical characterization of NF-H, the largest mammalian neurofilament component; intermediate filament-type sequences followed by unique carboxy-terminal extension. EMBO J. 4: 57-63.

Goldberg, S. and A.J. Coulombre. 1972. Topographical development of the nerve fiber layer in the chick retina. A whole mount study. I. Comp. Neurol. 146: 507-518.

Gubler, K. and B.J. Hoffmann. 1983. A simple and very efficient method for generating cDNA libraries. Gene 25: 263-269.

Hafen, E., M. Levine, R.L. Garber, and W.J. Gehring. 1983. An improved in situ hybridization method for the detection of cellular RNAs in Drosophila tissue sections and its applica- 
tion for localizing transcripts of the homeotic Antennapedia gene complex. $E M B O$ J. 2: 617-623.

Herrmann, B., M. Bucan, P.E. Mains, A. Frischauf, L.M. Silver, and H. Lehrach. 1986. Genetic analysis of the proximal portion of the mouse $t$ complex: Evidence for a second inversion within $\mathrm{t}$ haplotypes. Cell 44: 469-476.

Hirokawa, N., M.A. Glicksman, and M.B. Willard. 1984. Organization of mammalian neurofilament polypeptides within the neuronal cytoskeleton. J. Cell Biol. 98: 1523-1536.

Hoffmann, P.N., J.W. Griffin, and D.L. Price. 1984. Control of axonal caliber by neurofilament transport. I. Cell Biol. 99: 705-714.

Hogue-Angeletti, R.J., J.Q. Trojanowski, M.J. Carden, W.W. Schlaepfer, and V.M.-Y. Lee. 1985. Domain structure of neurofilament subunits as revealed by monoclonal antibodies. $J$. Cell Biochem. 27: 181-187.

Hunt, P.H. and N. Brecha. 1984. The avian tectum: A synthesis of morphology and biochemistry. In Comparative neurology of the optic tectum (ed. H. Vanegas), pp. 619-648. Plenum, New York and London.

Huynh, T., R.A. Young, and R.W. Davis. 1985. Constructing and screening cDNA libraries in $\lambda$ gt 10 and $\lambda$ gt 11 . In DNA Cloning, A Practical Approach (ed. H.D. Glover), vol. I, pp. 49-78. IRL Press, Oxford.

Jacobson, M. 1978. Development of peripheral neural connections with muscles and sensory receptors. In Developmental Biology, 2nd ed. pp. 309-433. Plenum Press, New York.

Jones, S.M. and R.C. Williams. 1982. Phosphate content of mammalian neurofilaments. I. Biol. Chem. 257: 99029905.

Julien, J.P. and W.E. Mushynski. 1982. Multiple phosphorylation sites in mammalian neurofilament polypeptides. J. Biol. Chem. 257: 10467-10470.

Julien, J.P. and W.E. Mushynski. 1983. The distribution of phosphorylation sites among identified proteolytic fragments of mammalian neurofilaments. J. Biol. Chem. 258: 4019-4025.

Julien, J.-P., D. Meyer, D. Flavell, J. Hurst, and F. Grosveld, 1986. Cloning and developmental expression of the murine neurofilament gene family. Mol. Brain Res. 1: 243-250.

Jungherr, E.L. 1969. The neuroanatomy of the domestic fowl (gallus domesticus), Avian Diseases (special issue), Amherst, MA.

Kahn, A.J. 1974. An autoradiographic analysis of the time of appearance of neurons in the developing chick neural retina. Dev. Biol. 38: 30-40.

Kandel, E. 1983. Neurobiology and molecular biology: The second encounter. Cold Spring Harbor Symp. Quant. Biol. 48: 891-908.

Kaufmann, E.L., N. Geisler, and K. Weber. 1984. SDS-PAGE strongly overestimates the molecular masses of the neurofilament proteins. FEBS Lett. 170: 81-84.

Ksiezak-Reding, H. and S.-H. Yen. 1986. Human and bovine neurofilament proteins contain different amounts of phosphate and form a blue complex with the carbocyanine dye "stains-all". J. Cell Biol. 103: 421a.

Lasek, R.J., L. Phillips, M.J. Katz, and L. Autilio-Gambetti. 1985. Function and evolution of neurofilament proteins. Ann. N.Y. Acad. Sci. 455: 462-478.

Lee, V.M.-Y., M.J. Carden, and W. Schlaepfer. 1986a. Structural similarities and differences between neurofilament proteins from five different species as revealed using monoclonal antibodies. I. Neurosci. 6: 2179-2186.

Lee, V.M.-Y., M.J. Carden, and J.Q. Trojanowski. 1986b. Novel monoclonal antibodies provide evidence for the in situ existence of a nonphosphorylated form of the largest neurofilament subunit. $/$. Neurosci. 6: 850-858.
Lewis, S.A. and N.J. Cowan. 1985. Genetics, evolution, and expression of the 68,000-mol-wt neurofilament protein: Isolation of a cloned cDNA probe. J. Cell Biol. 100: 843-850.

Lewis, S.A. and N.J. Cowan. 1986. Anomalous placement of introns in a member of the intermediate filament multigene family: An evolutionary conundrum. Mol. Cell. Biol. 6: $1529-1534$.

Liem, R.K.H., S.S.M. Chin, E. Moraru, and E. Wang. 1985. Monoclonal antibodies to epitopes on different regions of the 200,000 dalton neurofilament protein. Exp. Cell. Res. 156: $419-428$.

Liesi, P., J.-P. Julien, P. Vilja, F. Grosveld, and L. Rechardt. 1986. Specific detection of neuronal cell bodies: In situ hybridization with a biotin-labeled neurofilament cDNA probe. J. Histochem. Cytochem. 34: 923-926.

Maniatis, T., E.F. Fritsch, and J. Sambrook. 1982. Molecular cloning: A laboratory manual. Cold Spring Harbor Laboratory, Cold Spring Harbor, New York.

Mason, P.J. and C.J. Williams. 1985. Hybridisation in the analysis of recombinant DNA. In Nucleic acid hybridization: $A$ practical approach (eds. B.D. Hames and S.J. Higgins), pp. 113-160. IRL Press, Oxford.

Milner, J. and J.G. Sutcliffe. 1983. Gene expression in rat brain. Nucleic Acids Res. 11: 5497-5520.

Norrander, J., T. Kempe, and J. Messing. 1983. Construction of improved M13 vectors using oligodeoxynucleotide-directed mutagenesis. Gene 26: 101-106.

Peng, I., L.I. Binder, and M.M. Black. 1986. Biochemical and immunological analyses of cytoskeletal domains of neurons. I. Cell Biol. 102: 252-262.

Purves, D. and J.W. Lichtman. 1985. Formation of synapses. In Principles of neural development, pp. 205-328. Sinauer Assoc., Sunderland, Massachusetts.

Sanger, F., S. Nicklen, and A.R. Coulson. 1977. DNA sequencing with chain-terminating inhibitors. Proc. Natl. Acad. Sci. 74: 5463-5467.

Sargent, T.D. and I.B. Dawid. 1983. Differential gene expression in the gastrula of Xenopus laevis. Science 222: 135-139.

Scott, M.R.D., K. Westphal, and P.W. Rigby. 1983. Activation of mouse genes in transformed cells. Cell 34: 557-567.

Shaw, G., E. Debus, and K. Weber. 1984. The immunological relatedness of neurofilament proteins of higher vertebrates. Eur. J. Cell Biol. 34: 130-136.

Shivers, B., B.S. Schachter, and D.W. Pfaff. 1986. In situ hybridization for the study of gene expression in the brain. Methods Enzymol. 124: 497-510.

Sperry, R.W. 1963. Chemoaffinity in the orderly growth of nerve fiber patterns and connections. Proc. Natl. Acad. Sci. 50: $703-710$.

Thanos, S., F. Bonhoeffer, and U. Rutishauser. 1984. Fiber-fiber interaction and tectal cues influence the development of the chicken retinotectal projection. Proc. Natl. Acad. Sci. 81: 1906-1910.

Weber, K., G. Shaw, M. Osborn, E. Debus, and N. Geisler. 1983. Neurofilaments, a subclass of intermediate filaments: Structure and expression. Cold Spring Harbor Symp. Quant. Biol. 46: 717-729.

Weber, K. and N. Geisler. 1984. Intermediate filaments-From wool alpha-keratins to neurofilaments: A structural overview. In Cancer Cells 1: The transformed phenotype led. A.J. Levine, G.F. Vande Woude, W.C. Topp, and J.D. Watson), pp. 153-159. Cold Spring Harbor Laboratory, Cold Spring Harbor, New York.

Wible, B., K. Smith, and K. Angelides. 1986. Resolution of neurofilament phosphoprotein kinase activities: Identification of a neurofilament specific kinase. J. Cell. Biol. 103: 419a. 


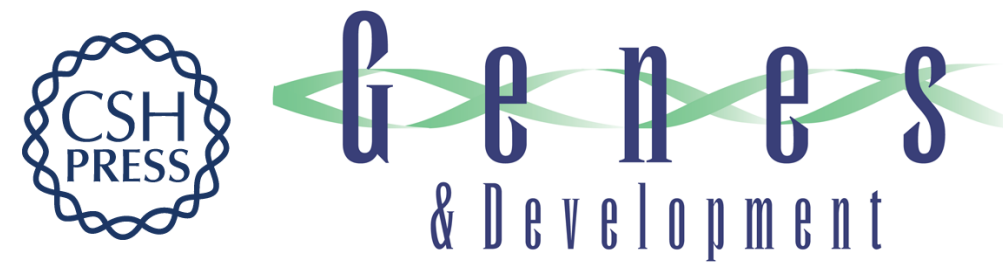

\section{Identification of gene products expressed in the developing chick visual system: characterization of a middle-molecular-weight neurofilament cDNA.}

D Zopf, I Hermans-Borgmeyer, E D Gundelfinger, et al.

Genes Dev. 1987, 1:

Access the most recent version at doi:10.1101/gad.1.7.699

References This article cites 54 articles, 21 of which can be accessed free at:

http://genesdev.cshlp.org/content/1/7/699.full.html\#ref-list-1

License

Email Alerting Receive free email alerts when new articles cite this article - sign up in the box at the top

Service right corner of the article or click here.

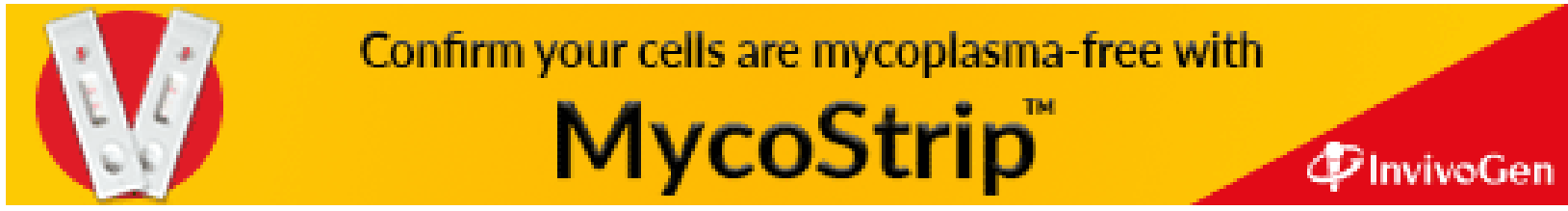

